\title{
Effect of type of fiber, site of fermentation, and method of analysis on digestibility of soluble and insoluble fiber in rabbits ${ }^{1}$
}

\author{
R. Abad-Guamán, R. Carabaño, M. S. Gómez-Conde, and J. García ${ }^{2}$ \\ Departamento de Producción Animal, E.T.S.I. Agrónomos, \\ Universidad Politécnica de Madrid, Ciudad Universitaria, 28040 Madrid, Spain
}

\begin{abstract}
The effect of type of fiber, site of fermentation, method for quantifying insoluble and soluble dietary fiber, and their correction for intestinal mucin on fiber digestibility were examined in rabbits. Three diets differing in soluble fiber were formulated (8.5\% soluble fiber, on DM basis, in the low soluble fiber [LSF] diet; $10.2 \%$ in the medium soluble fiber [MSF] diet; and $14.5 \%$ in the high soluble fiber [HSF] diet). They were obtained by replacing half of the dehydrated alfalfa in the MSF diet with a mixture of beet and apple pulp (HSF diet) or with a mix of oat hulls and soybean protein (LSF diet). Thirty rabbits with ileal T-cannulas were used to determine ileal and fecal digestibility. Cecal digestibility was determined by difference between fecal and ileal digestibility. Insoluble fiber was measured as NDF, insoluble dietary fiber (IDF), and in vitro insoluble fiber, whereas soluble fiber was calculated as the difference between total dietary fiber (TDF) and NDF (TDF-NDF), IDF (TDF-IDF), and in vitro insoluble fiber (TDF-in vitro insoluble fiber). The intestinal mucin content was used to correct the TDF and soluble fiber digestibility. Ileal and fecal concentration of mucin increased from the LSF to the HSF diet group $(P<0.01)$. Once corrected for intestinal mucin, ileal and fecal digestibility of
\end{abstract}

TDF and soluble fiber increased whereas cecal digestibility decreased $(P<0.01)$. Ileal digestibility of TDF increased from the LSF to the HSF diet group (12.0 vs. $28.1 \% ; P<0.01$ ), with no difference in the cecum $(26.4 \%)$, resulting in a higher fecal digestibility from the LSF to the HSF diet group $(P<0.01)$. Ileal digestibility of insoluble fiber increased from the LSF to the HSF diet group (11.3 vs. $21.0 \% ; P<0.01$ ), with no difference in the cecum (13.9\%) and no effect of fiber method, resulting in a higher fecal digestibility for rabbits fed the HSF diet compared with the MSF and LSF diet groups $(P<0.01)$. Fecal digestibility of NDF was higher compared with IDF or in vitro insoluble fiber $(P<0.01)$. Ileal soluble fiber digestibility was higher for the HSF than for the LSF diet group (43.6 vs. $14.5 \% ; P<0.01)$ and fiber method did not affect it. Cecal soluble fiber digestibility decreased from the LSF to the HSF diet group (72.1 vs. $49.2 \% ; P<0.05$ ). The lowest cecal and fecal soluble fiber digestibility was measured using TDF-NDF $(P<0.01)$. In conclusion, a correction for intestinal mucin is necessary for ileal TDF and soluble fiber digestibility whereas the selection of the fiber method has a minor relevance. The inclusion of sugar beet and apple pulp increased the amount of TDF fermented in the small intestine.

Key words: digestibility, insoluble dietary fiber, intestinal mucin, rabbit, soluble dietary fiber

\section{INTRODUCTION}

\footnotetext{
${ }^{1}$ We are grateful to the Comisión Interministerial de Ciencia y Tecnología (CICYT; projects AGL2001-2796 and AGL200800627) and Comunidad de Madrid (project S2009/AGR-1704) for the financial support and to the SENESCYT-Ecuador for the $\mathrm{PhD}$ grant obtained by Mr. Abad-Guamán.

${ }^{2}$ Corresponding author: javier.garcia@upm.es

Received November 28, 2014.

Accepted March 23, 2015.
}

Soluble fiber is not usually measured in rabbit diets in spite of its positive effect on rabbit health (Trocino et al., 2013). This circumstance is explained by the higher complexity of the available methodology for soluble fiber compared with that of insoluble fiber and the lack of agreement on the adequate methods, because most of the methods do not resemble the physiological conditions (Monro, 1993). Soluble dietary fiber can be 
determined as the difference between total dietary fiber (TDF) and the insoluble fiber (Van Soest et al., 1991). The soluble fiber calculated as the difference between TDF and NDF (TDF-NDF) is commonly used (Xiccato et al., 2012), but this value is higher than the value obtained from other methods (Abad et al., 2013).

The benefit of soluble fiber on rabbit health might be related to the improvement of gut barrier function in the small intestine and the fermentability of this fraction along the digestive tract (Trocino et al., 2013). Therefore, the determination of the ileal and cecal digestibility of soluble fiber would be of interest. Furthermore, the nutritional meaning of each method for soluble fiber determination might be different and worthy of being clarified. Previous results in rabbits (Gidenne, 1992) and pigs (Jørgensen et al., 1996; Wilfart et al., 2007) reported poor degradability of plant cell walls before the cecum according to their low or even negative ileal digestibility. These results might be related to the presence of endogenous carbohydrates in ileal digesta that would be recovered in TDF analysis. Abad et al. (2013) reported that intestinal mucins are partially retained in the TDF residue, leading to an overestimation of ileal TDF content, and proposed a simple correction.

The aim of this work was to identify the effects of type of fiber (low, medium, and high soluble fiber level), site of fermentation, method to quantify insoluble and soluble fiber, and correction of the intestinal soluble fiber content for intestinal mucins on the digestibility of fiber fractions in rabbits.

\section{MATERIALS AND METHODS}

\section{Diets}

Three diets with different soluble fiber content (determined as the difference between TDF and NDF) were formulated (Table 1). The low soluble fiber (LSF), medium soluble fiber (MSF), and high soluble fiber (HSF) diets contained $8.5,10.2$, and $14.5 \%$ of soluble fiber (on DM basis), respectively. The MSF diet had dehydrated alfalfa as the main source of fiber. The other 2 diets were formulated by replacing half of the dehydrated alfalfa used in the MSF diet by a mixture of beet and apple pulp (75:25; HSF diet) or by a combination of oat hulls and soya bean protein concentrate (Soycomil P-economy; Loders Croklaan, Wormerveer, The Netherlands; 88:12; LSF diet). These 3 diets were formulated to contain 12.5 MJ DE/kg DM and 12 g digestible CP/MJ DE according to the nutrient requirements of breeding does (de Blas and Mateos, 2010). They also had similar levels of starch and CP and TDF, which ranged from 40.9 to $42.5 \%$ DM (Table 1). Additionally, they contained robenidine hydrochloride (Cycostat; Zoetis, Paris, France) and $0.5 \%$ of alfalfa meal labeled with $\mathrm{Yb}_{2} \mathrm{O}_{3}$ as indigestible marker (Udén et al., 1980).

\section{Animals and Housing}

Thirty New Zealand White $\times$ Californian rabbit does weighing 4,555 $\pm 63 \mathrm{~g}$ were surgically fitted with a glass T-cannula at the ileum, 10 to $15 \mathrm{~cm}$ before the ileocecocolic junction, according to the procedure described by Gidenne et al. (1988) and in compliance with the Spanish guidelines for the care and use of animals in research (Spanish Royal Decree 1201/2005; BOE, 2005). After 6 wk of recovery, rabbits reached their previous level of ADFI and were ready to begin the trial. Animals were individually housed in wire metabolism cages measuring 405 by 510 by $320 \mathrm{~mm}$ that allowed feces collection. Rabbits had ad libitum access to feed and water. The housing conditions were controlled during the whole experimental period as follows: a $12 \mathrm{~h}$ light:dark cycle was established, the light was switched on at $0730 \mathrm{~h}$, and temperature was kept between 15 and $24^{\circ} \mathrm{C}$ by heating and cooling systems combined with continuous forced ventilation.

\section{Experimental Procedure}

Animals were randomly allotted to each experimental diet (10 rabbits/diet). After $14 \mathrm{~d}$ of adaptation period to the diets, the feed intake was recorded and the whole fecal excretion was collected for 4 consecutive days. Following the hard feces collection, 2 ileal samples from each rabbit were gathered under gravity for $1 \mathrm{~h}$ during 2 consecutive days (1/d) and mixed together. Both ileal samples were collected from 1900 to $2100 \mathrm{~h}$ to avoid the effect of the soft feces excretion period on the protein ileal flow (Merino and Carabaño, 2003). Fecal and ileal samples were stored at $-20^{\circ} \mathrm{C}$, frozen dried, and ground to $1 \mathrm{~mm}$ for further analysis. The samples were individually ground to determine $\mathrm{DM}, \mathrm{Yb}$, ash, GE, CP, starch, TDF, insoluble dietary fiber (IDF) according to the AOAC (AOAC, 2000), NDF, 2-step in vitro pepsin/pancreatin DM indigestibility (in vitro insoluble fiber), and soluble fiber calculated as the difference between TDF and IDF (TDF-IDF), soluble fiber calculated as the difference between TDF and in vitro insoluble fiber (TDF-in vitro insoluble fiber), or TDF-NDF. The apparent fecal digestibility of DM and dietary components $(\mathrm{OM}, \mathrm{GE}, \mathrm{CP}$, starch, TDF, insoluble fiber, and soluble fiber) were determined according to the European reference method (Perez et al., 1995). The apparent ileal digestibility of DM and dietary components (OM, CP, starch, TDF, insoluble fiber, and soluble fiber) were determined by the dilution technique using $\mathrm{Yb}$ as a marker as follows: 
Table 1. Ingredient and chemical composition of experimental diets (low soluble fiber, medium soluble fiber, or high soluble fiber diet)

\begin{tabular}{|c|c|c|c|}
\hline \multirow[b]{2}{*}{ Item } & \multicolumn{3}{|c|}{ Type of fiber } \\
\hline & $\begin{array}{l}\text { Low } \\
\text { soluble }\end{array}$ & $\begin{array}{l}\text { Medium } \\
\text { soluble }\end{array}$ & $\begin{array}{c}\text { High } \\
\text { soluble }\end{array}$ \\
\hline \multicolumn{4}{|l|}{ Ingredient, $\%$ as fed basis } \\
\hline Dehydrated alfalfa & 13.9 & 28.3 & 13.9 \\
\hline Oat hulls & 14.7 & - & - \\
\hline Beet pulp & - & 2.30 & 15.0 \\
\hline Apple pulp & - & - & 5.00 \\
\hline Soybean meal concentrate & 2.00 & - & - \\
\hline Boiled wheat & 32.3 & 32.3 & 32.3 \\
\hline Wheat bran & 8.40 & 8.40 & 8.40 \\
\hline Sunflower meal & 7.10 & 7.10 & 7.10 \\
\hline Soybean meal & 11.1 & 11.1 & 11.1 \\
\hline Sunflower hulls & 4.40 & 6.00 & 4.40 \\
\hline Lard & 3.30 & 2.30 & 0.50 \\
\hline Dehydrated alfalfa mordanced with $\mathrm{Yb}$ & 0.50 & 0.50 & 0.50 \\
\hline L-lysine HCL & 0.45 & 0.40 & 0.45 \\
\hline DL-methionine & 0.10 & 0.10 & 0.10 \\
\hline L-threonine & 0.15 & 0.10 & 0.15 \\
\hline Sodium chloride & 0.50 & 0.60 & 0.40 \\
\hline Calcium oxide & 0.60 & - & 0.20 \\
\hline Mineral/vitamin premix ${ }^{1}$ & 0.50 & 0.50 & 0.50 \\
\hline \multicolumn{4}{|l|}{ Analyzed chemical composition, \% DM } \\
\hline $\mathrm{DM}$ & 91.8 & 91.4 & 91.7 \\
\hline Ash & 6.54 & 7.10 & 6.72 \\
\hline $\mathrm{CP}$ & 19.9 & 20.3 & 19.7 \\
\hline $\mathrm{CP}-\mathrm{TDF}^{2}$ & 5.21 & 5.30 & 4.02 \\
\hline CP-IDF ${ }^{3}$ & 2.40 & 2.21 & 1.74 \\
\hline CP-NDF 4 & 3.44 & 4.20 & 3.72 \\
\hline CP-in vitro insoluble fiber ${ }^{5}$ & 5.12 & 5.20 & 3.84 \\
\hline Ether extract & 5.91 & 5.53 & 3.74 \\
\hline Starch & 21.1 & 20.8 & 20.5 \\
\hline TDF & 41.4 & 40.9 & 43.5 \\
\hline \multicolumn{4}{|l|}{ Insoluble fiber } \\
\hline IDF & 33.6 & 30.9 & 30.4 \\
\hline $\mathrm{NDF}$ & 32.9 & 30.7 & 29.0 \\
\hline In vitro insoluble fiber & 31.8 & 30.9 & 30.2 \\
\hline ADFom $^{6}$ & 16.2 & 16.4 & 16.9 \\
\hline ADLom $^{7}$ & 3.92 & 4.71 & 3.74 \\
\hline \multicolumn{4}{|l|}{ Soluble fiber } \\
\hline TDF-IDF ${ }^{8}$ & 7.82 & 9.96 & 13.1 \\
\hline TDF-NDF ${ }^{9}$ & 8.54 & 10.2 & 14.5 \\
\hline TDF-in vitro insoluble fiber ${ }^{10}$ & 9.61 & 10.0 & 13.3 \\
\hline GE, MJ/kg DM & 19.1 & 19.0 & 18.6 \\
\hline \multicolumn{4}{|l|}{ Calculated chemical composition, ${ }^{11} \% \mathrm{DM}$} \\
\hline Lysine & 1.26 & 1.18 & 1.22 \\
\hline Methionine & 0.41 & 0.41 & 0.40 \\
\hline Methionine + cysteine & 0.72 & 0.72 & 0.70 \\
\hline
\end{tabular}

${ }^{1}$ Provided by Ibérica de Nutrición Animal S.L. (Madrid, Spain). Mineral and vitamin composition (per $\mathrm{kg}$ of complete diet): $40 \mathrm{mg}$ of $\mathrm{Mn}$ as $\mathrm{MnO}$, $50 \mathrm{mg}$ of $\mathrm{Zn}$ as $\mathrm{ZnO}, 1.25 \mathrm{mg}$ of I as KI, $40 \mathrm{mg}$ of Fe as $\mathrm{FeSO}_{4}, 25 \mathrm{mg}$ of $\mathrm{Cu}$ as $\mathrm{CuSO}_{4}, 0.5 \mathrm{mg}$ of $\mathrm{Co}$ as $\mathrm{CoSO}_{4}, 250 \mathrm{mg}$ of choline chloride, $2 \mathrm{mg}$ of riboflavin, $5 \mathrm{mg}$ of calcium D-pantothenate, $15 \mathrm{mg}$ of nicotinic acid, $1 \mathrm{mg}$ of menadione sodium bisulfite, 9,000 IU of vitamin A as retinyl acetate, 1,800 IU of vitamin $\mathrm{D}_{3}$ as cholecalcipherol, $12.5 \mathrm{IU}$ of vitamin $\mathrm{E}$ ileal apparent digestibility ofDM $=[1-($ dietary $\mathrm{Yb}$ concentration/ileal $\mathrm{Yb}$ concentration) $] \times 100$ and

ileal apparent digestibility of dietary components $=[1-($ dietary $\mathrm{Yb}$ concentration $\times$ ileal component concentration/ileal $\mathrm{Yb}$ concentration $\times$ dietary component concentration) $] \times 100$.

Furthermore, the intestinal crude mucin in ileal and fecal digesta was determined to express TDF and soluble fiber without intestinal mucins (Abad et al., 2013). The cecal digestibility of each chemical constituent was calculated for each rabbit as the difference between the fecal and ileal digestibility. Cecal digestibility of mucins was determined for each rabbit as the difference between mucin ileal flow and mucin fecal excretion.

\section{Analytical Methods}

Procedures of the AOAC (2000) were used to determine DM (method 934.01), ash (method 942.05), CP (method 968.06), ether extract (method 920.39), starch (amyloglucosidase- $\alpha$-amylase method; method 996.11), TDF (method 985.29), and IDF (method 991.42). Dietary NDF was determined using the filter bag system (Ankom Technology, Macedon, NY) according to Mertens et al. (2002), and a thermostable amylase without any sodium sulfite was added. It was corrected for its own ash and protein as indicated for IDF. Dietary ADF and ADL were analyzed according to the AOAC (2000; method 973.187) and Van Soest et al. (1991), respectively. The in vitro insoluble fiber was performed in Ankom bags (Ankom Technology), and the indigestible residue was corrected for CP and ash (Abad et al., 2013). The soluble fiber was calculated by difference as TDF-IDF, TDF-in vitro insoluble fiber, or TDF-NDF. Gross energy was

as $\boldsymbol{\alpha}$-tocopherol acetate, $0.01 \mathrm{mg}$ of cyanocobalamin, $1 \mathrm{mg}$ of thiamine, and $66 \mathrm{mg}$ of robenidine hydrochloride (Cycostat; Zoetis, Paris, France).

${ }^{2} \mathrm{CP}-\mathrm{TDF}=\mathrm{CP}$ linked to total dietary fiber (TDF).

${ }^{3} \mathrm{CP}-\mathrm{IDF}=\mathrm{CP}$ linked to insoluble dietary fiber (IDF).

${ }^{4} \mathrm{CP}-\mathrm{NDF}=\mathrm{CP}$ linked to NDF; NDF $=\boldsymbol{\alpha}$-amylase neutral detergent fiber corrected for ash.

${ }^{5} \mathrm{CP}$-in vitro insoluble fiber $=\mathrm{CP}$ linked to in vitro insoluble fiber.

${ }^{6} \mathrm{ADFom}=\mathrm{ADF}$ corrected for ash.

${ }^{7} \mathrm{ADLom}=\mathrm{ADL}$ corrected for ash.

${ }^{8} \mathrm{TDF}-\mathrm{IDF}=$ soluble fiber calculated as difference between TDF and IDF.

${ }^{9} \mathrm{TDF}-\mathrm{NDF}=$ soluble fiber calculated as the difference between TDF and NDF.

${ }^{10} \mathrm{TDF}-$ in vitro insoluble fiber $=$ soluble fiber calculated as difference between TDF and in vitro insoluble fiber.

${ }^{11}$ Calculated values according to Fundacion Española para el Desarrollo de la Nutrición Animal (De Blas et al., 2003). 
determined by adiabatic calorimetry. Diets were analyzed in triplicate, and ileal digesta and feces were analyzed in duplicate. One gram of ileal content and $3 \mathrm{~g}$ of feces from each rabbit were used to analyze their crude mucin content, which was determined using the method of precipitation with ethanol (Leterme et al., 1998; Romero et al., 2011) and using pectinase (Sigma P2401; SigmaAldrich, St. Louis, MO) to remove soluble fiber (Abad et al., 2013). Crude protein on fecal mucin was determined using only 1 pooled sample for each treatment due to the small amount of residue obtained. Additionally, the $\mathrm{Yb}$ content of diets and ileal digesta were analyzed by atomic absorption spectrometry (Smith Hieftje 22; Thermo Jarrel Ash, Andover, MA; García et al., 1999).

\section{Statistical Analysis}

Repeated measures analysis was used to analyze the results obtained for apparent ileal and cecal digestibility using a mixed model (SAS Inst. Inc., Cary, NC). The model for DM, OM, and starch digestibility included, as fixed sources of variation, the soluble fiber level (diet), the site of digestion (ileum vs. cecum), and their interaction. The model for CP and TDF digestibility included, as fixed sources of variation, the soluble fiber level (diet), the site of digestion/fermentation, the mucin correction, and their interactions. The model for insoluble fiber digestibility included, as fixed effects, the soluble fiber level (diet), the site of fermentation, the method, and their interactions. The fixed effects of the model for soluble fiber digestibility were the soluble fiber level (diet), the site of fermentation, the method, the mucin correction, and their interactions. To compare the insoluble with the corrected soluble fiber digestibility, a model was used containing soluble fiber level (diet), site of fermentation (ileum vs. cecum), fiber fraction (insoluble vs. soluble), and method as fixed sources of variation. The model for daily fermented fiber (once corrected for mucins) included DMI as covariate and the soluble fiber level (diet), site of fermentation (ileum vs. cecum), fiber fraction (insoluble vs. soluble), and method as fixed sources of variation. In all cases, the rabbit was included as a random variable in the model. A compound symmetry structure was fitted because it showed the lowest value of the Schwarz Bayesian criterion (Littell et al., 1998).

The results obtained for fecal digestibility were analyzed using a mixed model considering the soluble fiber level (diet) as the main source of variation for DM, OM, starch, and GE digestibility. The model for fecal CP and TDF digestibility included, as fixed sources of variation, the effect of the soluble fiber level (diet) and the mucin correction; for insoluble fiber digestibility, the model included the soluble fiber level (diet) and the method; and for the soluble fiber digest- ibility, the model included the soluble fiber level (diet), method, and mucin correction.

The model for the ileal flow of dietary components had, as source of variation, the soluble fiber level (diet) and the DMI as a covariate and for insoluble and mucin corrected soluble fiber also contained the method. In these models, all the interactions among the fixed factors were also considered. The data are presented as least squares means, and they were compared using a protected $t$ test. Linear regressions between all measurements of the amount of insoluble and soluble fermented fiber using different methods were determined including feed intake as covariate.

\section{RESULTS}

The DMI did not differ among rabbits fed different dietary treatments $(151,141$, and $132 \mathrm{~g} \mathrm{DM} / \mathrm{d}$ for the LSF, MSF, and HSF diets, respectively; SEM = 10.4, $P=0.44$; data not shown). In rabbits fed the HSM diet, the average of ileal and cecal digestibility of DM and $\mathrm{OM}$ increased by $11 \%$ compared with the other 2 groups $(P<0.01$; Table 2$)$. However, the type of diet did not influence ileal and cecal DM, OM, and starch digestibility. In the ileum, $75 \%$ of the fecal digestible DM and OM was digested and almost all of the fecal digestible starch $(99 \% ; P<0.01)$ was digested. However, fecal DM, OM, and GE digestibility of rabbits fed the HSF diet were $9 \%$ higher than those of rabbits fed the other 2 diets $(P<0.01)$.

Ileal and fecal concentration of crude mucin increased from the LSF to the HSF diet by 78 and $46 \%$ $(P<0.01$; Table 3$)$. In addition, the ileal crude mucin flow (g DM/d) of the rabbits fed the HSF was higher than that of rabbits fed the LSF diet $(P=0.004)$. A similar effect, but smaller in magnitude, was observed for the fecal crude mucin flow when it was expressed per kilogram of DMI $(P=0.031)$. The apparent cecal crude mucin fermentation of the rabbits fed the HSF diet was higher than that of rabbits fed the MSF and LSF diets ( 90.9 vs. $84.8 \% ; P=0.014)$. Ileal and fecal crude mucin contained 24.3 and $21.6 \% \mathrm{CP}$.

Rabbits fed the LSF diet showed an ileal CP digestibility $8 \%$ higher than rabbits fed the other 2 diets $(64.9$ vs. $59.8 \% ; P<0.01$; Table 4$)$. These values increased by 3.7 percentage units when they were corrected for the ileal mucin CP (59.7 vs. 63.4; $P=$ 0.002). No difference was found in cecal CP digestibility among rabbits fed the three experimental diets, and it decreased by $3.3 \%$ units when the mucin $\mathrm{CP}$ was considered (12.8 vs. $9.52 \% ; P=0.006)$. Fecal CP digestibility of rabbits fed the LSF diet was $8 \%$ higher than that of rabbits fed the MSF diet $(P=0.002)$, with the HSF diet generating an intermediate value. Once 
Table 2. Effect of type of fiber and site of digestion on apparent ileal, cecal, and fecal digestibility of dietary components in rabbits

\begin{tabular}{|c|c|c|c|c|}
\hline Item & DM & $\mathrm{OM}$ & Starch & GE \\
\hline \multicolumn{5}{|l|}{ Ileal digestibility, $\%$} \\
\hline Low soluble fiber & 48.9 & 50.9 & 98.3 & - \\
\hline Medium soluble fiber & 46.2 & 48.2 & 98.1 & - \\
\hline High soluble fiber & 52.1 & 54.6 & 98.0 & - \\
\hline \multicolumn{5}{|l|}{ Cecal digestibility, $\%$} \\
\hline Low soluble fiber & 16.2 & 13.9 & 1.15 & - \\
\hline Medium soluble fiber & 18.2 & 15.7 & 1.52 & - \\
\hline High soluble fiber & 18.4 & 17.8 & 1.33 & - \\
\hline SEM $^{1}$ & & & & - \\
\hline Type of fiber (diet) & 0.42 & 0.54 & 0.064 & - \\
\hline Site of digestion & 1.62 & 1.81 & 0.217 & - \\
\hline Type of fiber $\times$ site of digestion & 1.99 & 2.25 & 0.269 & - \\
\hline \multicolumn{5}{|l|}{$P$-value } \\
\hline Type of fiber (diet) & $<0.001$ & $<0.001$ & 0.31 & - \\
\hline Site of digestion & $<0.001$ & $<0.001$ & $<0.001$ & - \\
\hline Type of fiber $\times$ site of digestion & 0.574 & 0.726 & 0.693 & - \\
\hline \multicolumn{5}{|l|}{ Fecal digestibility, $\%$} \\
\hline Low soluble fiber & $65.1^{\mathrm{b}}$ & $64.8^{\mathrm{b}}$ & 99.5 & $65.6^{\mathrm{b}}$ \\
\hline Medium soluble fiber & $64.4^{\mathrm{b}}$ & $63.9^{\mathrm{b}}$ & 99.6 & $64.3^{\mathrm{b}}$ \\
\hline High soluble fiber & $70.5^{\mathrm{a}}$ & $72.4^{\mathrm{a}}$ & 99.3 & $69.7^{\mathrm{a}}$ \\
\hline SEM $^{1}$ & 0.83 & 1.08 & 0.13 & 0.83 \\
\hline \multicolumn{5}{|l|}{$P$-value } \\
\hline Type of fiber (diet) & $<0.001$ & $<0.001$ & 0.267 & $<0.001$ \\
\hline
\end{tabular}

a,b Mean values in the same column for each site of digestion with a different superscript differ $(P<0.05)$.

${ }^{1} n=10 \mathrm{rabbits} /$ diet in each site of digestion corrected for fecal mucin $\mathrm{CP}$, fecal $\mathrm{CP}$ digestibility increased by $0.4 \%$ units $(P<0.01)$.

Ileal digestibility of TDF increased from the LSF to the HSF diet group (10.5 vs. $25.6 \% ; P<0.01$; Table 4 ), but the cecal digestibility of TDF was unaffected by the $\operatorname{diet}(28.2 \%$ on average), resulting in an interaction diet $\times$ site of fermentation $(P<0.01)$. Ileal TDF digestibility increased by $4.2 \%$ units when it was corrected for mucins $(P<0.01)$, whereas cecal digestibility decreased by $3.7 \%$ units $(P<0.01)$. As a result, an interaction mucin correction $\times$ site of fermentation was found $(P<$ 0.01 ). Once corrected for mucin content, around $40 \%$ of digestible TDF was fermented in the ileum and $60 \%$ in the cecum ( 18.5 vs. $26.4 \%$, respectively; $P<0.01$ ). However, it depended on the type of diet because the increment of dietary soluble fiber content raised the proportion of mucin corrected TDF fermented in the ileum (from 32 to $51 \%$ for the LSF to the HSF diets, respectively; $P<0.01$ ). Accordingly, rabbits fed the HSF diet fermented daily in the ileum more than double the TDF of those fed the MSF and LSF diets (16.7 vs. $7.7 \mathrm{~g}$ TDF/d; $P<0.01$; Fig. 1$)$ but a similar amount in the cecum (16.2 g TDF/d). Rabbits fed the MSF and LSF diets fermented double amount of TDF in the cecum than in the ileum (15.3 vs. $7.7 \mathrm{~g} \mathrm{TDF} / \mathrm{d} ; P<0.01 ;$ Fig. 1$)$. Fecal digestibility of TDF raised from 37.5 to $54.7 \%$ for the LSF and HSF diet groups, respectively $(P<0.01)$. Moreover, it increased by $0.5 \%$ units once corrected for fecal mucin $(P<0.01)$.

Ileal digestibility of insoluble fiber of rabbits fed the HSF was greater than for those fed the LSF diet (21.0 vs. $11.3 \% ; P<0.01$; Table 5$)$, but cecal digestibility was similar among the 3 diet groups (13.9\% on average), leading to an interaction between type of fiber $\times$ site of fermentation $(P=0.013)$. No effect of the methods used to determine insoluble fiber was found on its digestibility

Table 3. Effect of type of fiber (low soluble fiber, medium soluble fiber, or high soluble fiber diet) on ileal and fecal mucin content in rabbits

\begin{tabular}{|c|c|c|c|c|c|}
\hline \multirow[b]{2}{*}{ Item } & \multicolumn{3}{|c|}{ Type of fiber } & \multirow[b]{2}{*}{ SEM $^{1}$} & \multirow[b]{2}{*}{$P$-value } \\
\hline & Low soluble & Medium soluble & High soluble & & \\
\hline \multicolumn{6}{|l|}{ Ileal crude mucin } \\
\hline g DM/kg dry ileal digesta & $43.3^{\mathrm{c}}$ & $59.7^{\mathrm{b}}$ & $77.1^{\mathrm{a}}$ & 4.41 & $<0.001$ \\
\hline $\mathrm{g} \mathrm{DM} / \mathrm{d}$ & $3.20^{\mathrm{b}}$ & $3.80^{\mathrm{b}}$ & $5.64^{\mathrm{a}}$ & 0.48 & 0.004 \\
\hline $\mathrm{g} / \mathrm{kg}$ of DMI & $21.4^{\mathrm{c}}$ & $28.2^{\mathrm{b}}$ & $42.5^{\mathrm{a}}$ & 3.00 & $<0.001$ \\
\hline $\mathrm{CP}, \%$ ileal mucin & 25.3 & 24.3 & 23.2 & 0.70 & 0.136 \\
\hline \multicolumn{6}{|l|}{ Fecal crude mucin } \\
\hline $\mathrm{g} \mathrm{DM} / \mathrm{kg}$ of dry fecal digesta & $8.44^{b}$ & $11.0^{\mathrm{a}}$ & $12.3^{\mathrm{a}}$ & 0.62 & $<0.001$ \\
\hline $\mathrm{g} \mathrm{DM} / \mathrm{d}$ & 0.45 & 0.55 & 0.50 & 0.062 & 0.502 \\
\hline $\mathrm{g} / \mathrm{kg}$ of DMI & $2.94^{\mathrm{b}}$ & $3.95^{\mathrm{a}}$ & $3.66^{\mathrm{ab}}$ & 0.26 & 0.031 \\
\hline $\mathrm{CP}, \%$ fecal mucin ${ }^{2}$ & 22.6 & 21.4 & 20.8 & - & - \\
\hline Apparent cecal fermentation of mucin, $\%$ & $85.2^{\mathrm{b}}$ & $84.5^{\mathrm{b}}$ & $90.9^{\mathrm{a}}$ & 1.53 & 0.014 \\
\hline
\end{tabular}

${ }^{\mathrm{a}-\mathrm{c}}$ Mean values in the same row with a different superscript $\operatorname{differ}(P<0.05)$.

$1_{n}=10$ rabbits/diet.

${ }^{2} \mathrm{CP}$ on fecal mucin was determined using only 1 pooled sample for each treatment due to the small residue obtained. 
Table 4. Effect of type of fiber (low soluble fiber [LSF], medium soluble fiber [MSF], or high soluble fiber [HSF] diet), mucin correction, and site of digestion/fermentation on apparent ileal, cecal, and fecal digestibility of $\mathrm{CP}$ and total dietary fiber in rabbits

\begin{tabular}{|c|c|c|c|c|}
\hline \multirow[b]{2}{*}{ Mucin correction } & \multicolumn{2}{|c|}{$\mathrm{CP}$} & \multicolumn{2}{|c|}{ Total dietary fiber } \\
\hline & No & Yes & No & Yes \\
\hline \multicolumn{5}{|l|}{ Ileal digestibility, $\%$} \\
\hline LSF & $63.5^{\mathrm{a}}$ & $66.3^{\mathrm{a}}$ & $8.91^{\mathrm{b}}$ & $12.0^{\mathrm{b}}$ \\
\hline MSF & $57.6^{\mathrm{b}}$ & $61.5^{\mathrm{b}}$ & $10.9^{\mathrm{b}}$ & $15.5^{\mathrm{b}}$ \\
\hline HSF & $57.9^{\mathrm{b}}$ & $62.3^{\mathrm{b}}$ & $23.0^{\mathrm{a}}$ & $28.1^{\mathrm{a}}$ \\
\hline Average & 59.7 & 63.4 & 14.3 & 18.5 \\
\hline \multicolumn{5}{|l|}{ Cecal digestibility, $\%$} \\
\hline LSF & 11.9 & 9.43 & 28.4 & 25.8 \\
\hline MSF & 12.0 & 8.53 & 30.5 & 26.6 \\
\hline HSF & 14.5 & 10.6 & 31.4 & 26.9 \\
\hline Average & 12.8 & 9.52 & 30.1 & 26.4 \\
\hline \multicolumn{5}{|l|}{ SEM $^{1}$} \\
\hline Type of fiber (diet) & \multicolumn{2}{|c|}{0.57} & \multicolumn{2}{|c|}{0.68} \\
\hline Mucin correction/site of digestion ${ }^{2}$ & \multicolumn{2}{|c|}{0.53} & \multicolumn{2}{|c|}{0.56} \\
\hline Fiber method & \multicolumn{2}{|c|}{-} & \multicolumn{2}{|c|}{-} \\
\hline Type of fiber $\times$ site of digestion & \multicolumn{2}{|c|}{0.91} & \multicolumn{2}{|c|}{0.96} \\
\hline Mucin correction $\times$ site of digestion & \multicolumn{2}{|c|}{0.79} & \multicolumn{2}{|c|}{0.79} \\
\hline \multicolumn{5}{|l|}{$P$-value ${ }^{3}$} \\
\hline Type of fiber (diet) & \multicolumn{2}{|c|}{0.008} & \multicolumn{2}{|c|}{$<0.001$} \\
\hline Mucin correction & \multicolumn{2}{|c|}{0.817} & \multicolumn{2}{|c|}{0.742} \\
\hline Site of digestion & \multicolumn{2}{|c|}{$<0.001$} & \multicolumn{2}{|c|}{$<0.001$} \\
\hline Type of fiber $\times$ site of digestion & \multicolumn{2}{|c|}{0.004} & \multicolumn{2}{|c|}{$<0.001$} \\
\hline Mucin correction $\times$ site of digestion & \multicolumn{2}{|c|}{$<0.001$} & \multicolumn{2}{|c|}{$<0.001$} \\
\hline \multicolumn{5}{|l|}{ Fecal digestibility, $\%$} \\
\hline LSF & $75.4^{\mathrm{a}}$ & $75.7^{\mathrm{a}}$ & $37.3^{\mathrm{c}}$ & $37.7^{\mathrm{b}}$ \\
\hline MSF & $69.6^{\mathrm{b}}$ & $70.0^{\mathrm{b}}$ & $41.4^{\mathrm{b}}$ & $42.0^{\mathrm{b}}$ \\
\hline HSF & $72.5^{\mathrm{ab}}$ & $72.9^{\mathrm{ab}}$ & $54.5^{\mathrm{a}}$ & $55.0^{\mathrm{a}}$ \\
\hline Average & 72.5 & 72.9 & 44.4 & 44.9 \\
\hline SEM $^{1}$ & & & & \\
\hline Type of fiber (diet) & 1.1 & & 1.3 & \\
\hline Mucin correction & & & & \\
\hline Type of fiber $\times$ mucin correction & 1.1 & & 1.3 & \\
\hline$P$-value ${ }^{3}$ & & & & \\
\hline Type of fiber (diet) & & & $<0$ & \\
\hline Mucin correction & $<0$ & & $<0$. & \\
\hline Type of fiber $\times$ mucin correction & & & & \\
\hline
\end{tabular}

a,b Mean values in the same column and site of digestion/fermentation for each effect with a different superscript differ $(P<0.05)$.

$1_{n}=10$ rabbits/diet. Standard error of the mean values for interaction type of fiber $\times$ mucin correction $\times$ site of digestion/fermentation for ileal and cecal $\mathrm{CP}$ and total dietary fiber digestibility were 1.35 and 1.34 , respectively.

${ }^{2}$ Standard error of the mean values for mucin correction and site of digestion/fermentation were the same for $\mathrm{CP}$ and total dietary fiber.

${ }^{3}$ The interactions not shown were not significant $(P>0.20)$.

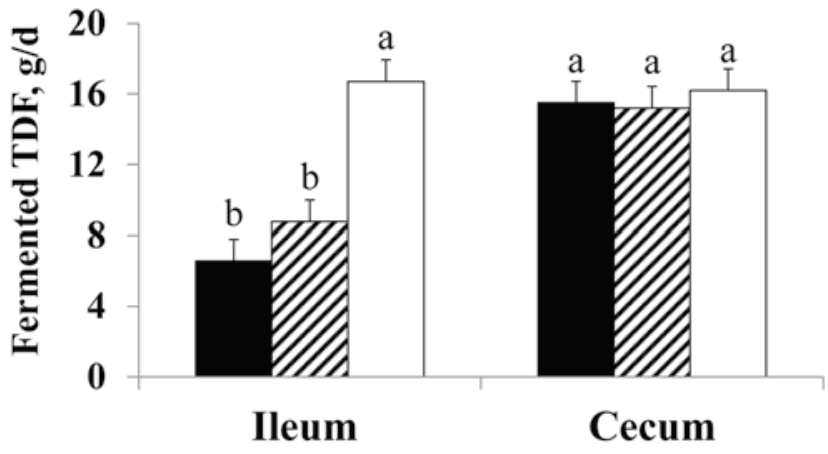

Figure 1. Effect of type of fiber (low [ $\mathbf{\square}$, medium [ $\mathbb{Z}$ ], or high soluble fiber diet $[\square]$ ) and site of fermentation (ileum vs. cecum) on the daily total dietary fiber (TDF) fermented (g TDF/d, corrected for mucin content and considering the DMI as covariate). $P_{\text {type }}$ of fiber $\times$ site of fermentation $<0.001$. Values are means $\pm \operatorname{SEM}(0.79 ; n=10)$. ${ }^{\text {a,b }}$ Within each segment mean values with a different letter differ $(P<0.05)$.

at the ileum or cecum. Ileal and cecal digestibility of insoluble fiber showed on average similar values (15.7 vs. $13.9 \% ; P=0.078)$. According to these results, approximately half of the total fermented insoluble fiber (53\%) occurred before the cecum. Consequently, the fecal digestibility of insoluble fiber was greater for rabbits fed the HSF diet than for those fed the MSF and LSF diets ( 37.7 vs. $25.5 \% ; P<0.01$; Table 4). Fecal digestibility of insoluble fiber measured as NDF was higher than that measured as IDF or in vitro insoluble fiber (31.4 vs. $28.7 \% ; P<0.01)$. The amounts of NDF, IDF, and in vitro insoluble fiber fermented $(\mathrm{g} / \mathrm{d})$ in the whole digestive tract were highly correlated $(r \geq 0.973, P<0.01)$. This correlation remained high between the amount of NDF and IDF fermented, in both the ileum and cecum $(r \geq$ $0.829, P<0.01)$. In contrast, the correlation between the in vitro insoluble fiber and the NDF or IDF fermented in the ileum and cecum decreased (from 0.445 to 0.569 ; $P<0.05$ ) or even disappeared (between in vitro insoluble fiber and IDF fermented in the cecum).

The rabbits fed the HSF diet had a greater ileal digestibility of soluble fiber than those fed the MSF and LSF diets (35.6 vs. $7.6 \%$, respectively; $P<0.01$; Table 5). It was $16.5 \%$ units greater when it was corrected using the ileal mucin content than the uncorrected value ( 8.69 vs. $25.2 \% ; P<0.01$ ). When the ileal soluble fiber digestibility was not corrected for mucin, it showed negative values for rabbits from the LSF and MSF diet groups ( -0.40 and $-1.13 \%)$, being positive only for those of the HSF diet group (27.6\%). Ileal digestibility of soluble fiber became positive for rabbits fed the LSF and MSF diets after its correction for mucin content (14.5 and 17.3\%), whereas it showed a higher value for those of HSF diet group (43.6\%). Once corrected for mucin content, the ileal digestibility of soluble fiber for each diet group was not affected by the fiber methodology used. Ileal digestibil- 
Table 5. Effect of type of fiber (low soluble fiber [LSF], medium soluble fiber [MSF], or high soluble fiber [HSF] diet), mucin correction, fiber method, and site of fermentation on apparent ileal, cecal, and fecal digestibility of insoluble and soluble fiber in rabbits

\begin{tabular}{|c|c|c|c|c|c|c|c|c|c|}
\hline \multirow{3}{*}{$\frac{\text { Fiber method }^{1}}{\text { Mucin correction }}$} & \multicolumn{3}{|c|}{ Insoluble fiber } & \multicolumn{6}{|c|}{ Soluble fiber } \\
\hline & \multirow[t]{2}{*}{$\begin{array}{c}\text { Insoluble } \\
\text { dietary fiber }\end{array}$} & \multirow[t]{2}{*}{$\begin{array}{c}\text { In vitro } \\
\text { insoluble fiber }\end{array}$} & \multirow[t]{2}{*}{$\mathrm{NDF}$} & \multicolumn{2}{|c|}{$\begin{array}{l}\text { Total dietary fiber- } \\
\text { insoluble dietary fiber }\end{array}$} & \multicolumn{2}{|c|}{$\begin{array}{l}\text { Total dietary fiber- } \\
\text { in vitro insoluble fiber }\end{array}$} & \multicolumn{2}{|c|}{$\begin{array}{l}\text { Total dietary } \\
\text { fiber-NDF }\end{array}$} \\
\hline & & & & No & Yes & No & Yes & No & Yes \\
\hline \multicolumn{10}{|l|}{ Ileal digestibility, \% } \\
\hline LSF & $12.1^{\mathrm{b}}$ & $10.7^{\mathrm{b}}$ & $11.0^{\mathrm{b}}$ & $-5.04^{b}$ & $11.4^{\mathrm{b}}$ & $2.86^{\mathrm{b}}$ & $16.2^{\mathrm{b}}$ & $0.98^{\mathrm{b}}$ & $15.9^{\mathrm{b}}$ \\
\hline MSF & $15.7^{\mathrm{ab}}$ & $14.8^{\mathrm{ab}}$ & $14.1^{\mathrm{b}}$ & $-3.78^{b}$ & $14.9^{\mathrm{b}}$ & $-1.02^{b}$ & $17.5^{\mathrm{b}}$ & $1.42^{\mathrm{b}}$ & $19.6^{\mathrm{b}}$ \\
\hline HSF & $20.7^{\mathrm{a}}$ & $20.9^{\mathrm{a}}$ & $21.4^{\mathrm{a}}$ & $28.5^{\mathrm{a}}$ & $45.2^{\mathrm{a}}$ & $27.9^{\mathrm{a}}$ & $44.4^{\mathrm{a}}$ & $26.4^{\mathrm{a}}$ & $41.4^{\mathrm{a}}$ \\
\hline Average & 16.2 & 15.5 & 15.5 & 6.55 & 23.8 & 9.92 & 26.0 & 9.59 & 25.7 \\
\hline \multicolumn{10}{|l|}{ Cecal digestibility, \% } \\
\hline LSF & 12.6 & 13.2 & 15.4 & $97.4^{\mathrm{a}}$ & $83.2^{\mathrm{a}}$ & $79.0^{\mathrm{a}}$ & $67.5^{\mathrm{a}}$ & $78.6^{\mathrm{a}}$ & $65.6^{\mathrm{a}}$ \\
\hline MSF & 9.56 & 10.1 & 14.1 & $95.7^{\mathrm{a}}$ & $79.4^{\mathrm{a}}$ & $93.5^{\mathrm{a}}$ & $77.4^{\mathrm{a}}$ & $79.9^{\mathrm{a}}$ & $64.1^{\mathrm{a}}$ \\
\hline HSF & 16.2 & 15.9 & 18.2 & $66.6^{\mathrm{b}}$ & $51.6^{\mathrm{b}}$ & $66.6^{\mathrm{b}}$ & $51.8^{\mathrm{b}}$ & $57.7^{\mathrm{b}}$ & $44.2^{\mathrm{b}}$ \\
\hline Average & 12.8 & 13.0 & 15.9 & 86.5 & 71.4 & 79.7 & 65.6 & 72.1 & 58.0 \\
\hline \multicolumn{10}{|l|}{ SEM $^{2}$} \\
\hline Type of fiber (diet) & \multicolumn{3}{|c|}{0.92} & \multicolumn{6}{|c|}{0.51} \\
\hline Mucin correction/site of fermentation ${ }^{3}$ & \multicolumn{3}{|c|}{0.72} & \multicolumn{6}{|c|}{1.05} \\
\hline Fiber method & \multicolumn{3}{|c|}{0.88} & \multicolumn{6}{|c|}{1.45} \\
\hline Type of fiber $\times$ site of fermentation & \multicolumn{3}{|c|}{1.26} & \multicolumn{6}{|c|}{1.78} \\
\hline Mucin correction $\times$ site of fermentation & \multicolumn{3}{|c|}{-} & \multicolumn{6}{|c|}{1.76} \\
\hline Fiber method $\times$ site of fermentation & & 1.26 & & & & & & & \\
\hline$P$-value ${ }^{4}$ & & & & & & & & & \\
\hline Type of fiber (diet) & & $<0.001$ & & & & & & & \\
\hline Mucin correction & & - & & & & & & & \\
\hline Fiber method & & 0.462 & & & & & & & \\
\hline Site of digestion & & 0.078 & & & & & & & \\
\hline Type of fiber $\times$ site of fermentation & & 0.013 & & & & & & & \\
\hline Mucin correction $\times$ site of digestion & & - & & & & & & & \\
\hline Fiber method $\times$ site of fermentation & & 0.284 & & & & & & & \\
\hline Fecal digestibility, $\%$ & & & & & & & & & \\
\hline LSF & $24.7^{\mathrm{b}}$ & $23.9^{\mathrm{b}}$ & $26.4^{\mathrm{b}}$ & 92.4 & 94.6 & $81.9^{\mathrm{b}}$ & $83.7^{\mathrm{b}}$ & $79.5^{\mathrm{b}}$ & $81.6^{\mathrm{b}}$ \\
\hline MSF & $25.2^{\mathrm{b}}$ & $24.9^{\mathrm{b}}$ & $28.2^{\mathrm{b}}$ & 91.9 & 94.3 & $92.5^{\mathrm{a}}$ & $94.9^{\mathrm{a}}$ & $81.4^{\mathrm{ab}}$ & $83.7^{\mathrm{ab}}$ \\
\hline HSF & $36.9^{\mathrm{a}}$ & $36.8^{\mathrm{a}}$ & $39.6^{\mathrm{a}}$ & 95.1 & 96.7 & $94.6^{\mathrm{a}}$ & $96.2^{\mathrm{a}}$ & $84.1^{\mathrm{a}}$ & $85.6^{\mathrm{a}}$ \\
\hline Average & $28.9^{\mathrm{B}}$ & $28.5^{\mathrm{B}}$ & $31.4^{\mathrm{A}}$ & 93.1 & 95.2 & 89.7 & 91.6 & 81.7 & 83.6 \\
\hline $\mathrm{SEM}^{2}$ & & & & & & & & & \\
\hline Type of fiber (diet) & & 1.84 & & & & & & & \\
\hline Mucin correction & & - & & & & & & & \\
\hline Fiber method & & 1.09 & & & & & & & \\
\hline Type of fiber $\times$ mucin correction & & - & & & & & & & \\
\hline Type of fiber $\times$ fiber method & & 1.86 & & & & & & & \\
\hline$P$-value ${ }^{4}$ & & & & & & & & & \\
\hline Type of fiber (diet) & & $<0.001$ & & & & & & & \\
\hline Mucin correction & & - & & & & & & & \\
\hline Fiber method & & $<0.001$ & & & & & & & \\
\hline Type of fiber $\times$ fiber method & & 0.503 & & & & & & & \\
\hline
\end{tabular}

a,b Mean values in the same column and site of fermentation for each effect with a different superscript differ $(P<0.05)$.

${ }^{\mathrm{A}, \mathrm{B}}$ Average values in the same row for insoluble fiber with a different superscript differ $(P<0.05)$.

${ }^{1} n=10$ rabbits/diet. Standard error of the mean values for interaction type of fiber $\times$ fiber method $\times$ site of fermentation for ileal and cecal insoluble and soluble fiber digestibility were 2.13 and 3.85 , respectively.

${ }^{2}$ Standard error of the mean value for interaction type of fiber $\times$ mucin correction $\times$ fiber method $\times$ site of fermentation for ileal and cecal insoluble fiber digestibility was 5.68. Standard error of the mean value for interaction type of fiber $\times$ mucin correction $\times$ fiber method for fecal soluble fiber digestibility was 1.31 .

${ }^{3}$ Standard error of the mean values for mucin correction and site of fermentation were the same for soluble fiber digestibility.

${ }^{4}$ The interactions not shown were not significant $(P>0.20)$. 


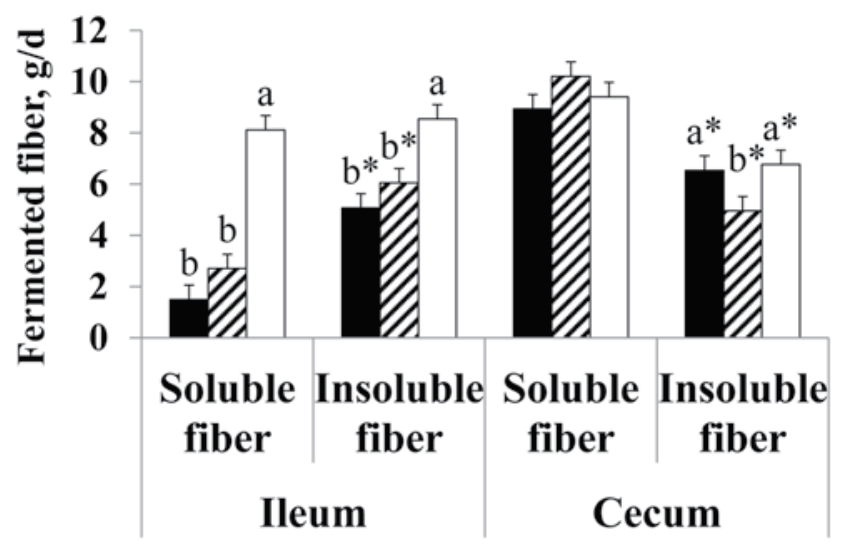

Figure 2. Effect of type of fiber (low [-], medium [ [Z], or high soluble fiber diet [ $\square]$ ), site of fermentation (ileum vs. cecum), and fiber fraction (soluble vs. insoluble) on daily fiber fermented ( $\mathrm{g} / \mathrm{d}$, corrected for mucin content and considering the DMI as covariate). Values for fermented soluble and insoluble fiber are the average of the 3 methods evaluated. $P_{\text {type of fiber } \times \text { site }}$ of fermentation $\times$ fiber fraction $=0.002$. Values are means $\pm \operatorname{SEM}(0.51 ; n=10)$. ${ }^{a, b}$ Within each combination type of fiber $\times$ site of fermentation mean values with a different letter differ $(P<0.05)$. ${ }^{*}$ Within each segment indicates that mean fiber fraction values for each type of fiber differ $(P<0.05)$.

ity of soluble fiber (corrected for mucin) was higher than that for insoluble fiber for rabbits fed the HSF $\operatorname{diet}(43.6$ vs. $21.0 \% ; P<0.01$ ), and no difference was detected for animals who received the LSF and MSF diets ( 15.9 vs. $13.1 \%)$. As a consequence, the amount of fermented soluble fiber (once corrected for mucin content) in the ileum was lower than the fermented insoluble fiber for rabbits fed the LSF diet (1.5 vs. 5.1 $\mathrm{g} / \mathrm{d} ; P<0.01 ;$ Fig. 2$)$ and the MSF $\operatorname{diet}(2.7$ vs. $6.0 \mathrm{~g} / \mathrm{d}$; $P<0.01$ ), but it was similar for those given the HSF $\operatorname{diet}(8.1 \mathrm{vs} .8 .5 \mathrm{~g} / \mathrm{d})$. In contrast to the ileal digestibility, cecal digestibility of soluble fiber was lower for the HSF compared with the MSF and LSF diet groups (56.4 vs. $80.1 \% ; P<0.01$ ), resulting in an interaction diet $\times$ site of fermentation $(P<0.01)$. Correction for ileal and fecal mucin content decreased cecal soluble fiber digestibility by $14.4 \%$ units compared with the uncorrected value $(P<0.01)$. This effect was opposite to that recorded in the ileum and led to an interaction mucin correction $\times$ site of fermentation $(P<0.01)$. Once corrected for ileal and fecal mucin content, digestibility of soluble fiber in the cecum was higher than in the ileum ( 65.0 vs. $25.2 \% ; P<0.01)$. However, it depended on the type of diet because the increment of dietary soluble fiber content raised the proportion of soluble fiber fermented in the ileum (from 14.5 to $43.6 \%$ for the LSF and HSF diet groups, respectively; $P<0.01)$ but decreased it in the cecum (72.1 vs. $49.2 \%$ for the HSF and the average of the MSF and LSF diet groups, respectively; $P<0.05)$. As a consequence, the amount of soluble fiber fermented in the cecum was greater than in the ileum for rabbits who received the LSH and MSF diets $(9.5$ vs. $2.1 \mathrm{~g} / \mathrm{d} ; P<$
Table 6. Effect of type of fiber (low soluble fiber, medium soluble fiber, or high soluble fiber diet) on ileal flow $(\mathrm{g} / \mathrm{d})$ of dietary components in rabbits

\begin{tabular}{|c|c|c|c|c|c|}
\hline \multirow[b]{2}{*}{ Item } & \multicolumn{3}{|c|}{ Type of fiber } & \multirow[b]{2}{*}{ SEM $^{1}$} & \multirow[b]{2}{*}{$P$-value } \\
\hline & $\begin{array}{c}\text { Low } \\
\text { soluble }\end{array}$ & $\begin{array}{c}\text { Medium } \\
\text { soluble }\end{array}$ & $\begin{array}{c}\text { High } \\
\text { soluble }\end{array}$ & & \\
\hline$\overline{\mathrm{DM}}$ & 71.9 & 77.5 & 69.6 & 2.57 & 0.108 \\
\hline $\mathrm{OM}$ & 64.6 & 69.0 & 61.4 & 2.46 & 0.119 \\
\hline $\mathrm{CP}$ & $10.0^{\mathrm{b}}$ & $11.7^{\mathrm{a}}$ & $11.8^{\mathrm{a}}$ & 0.40 & 0.006 \\
\hline CP-mucin ${ }^{2}$ & $0.75^{\mathrm{b}}$ & $1.07^{\mathrm{a}}$ & $1.22^{\mathrm{a}}$ & 0.074 & $<0.001$ \\
\hline $\mathrm{CP}-\mathrm{NDF}^{3}$ & 6.47 & 5.42 & 4.80 & 0.57 & 0.150 \\
\hline Starch & 0.51 & 0.58 & 0.60 & 0.078 & 0.706 \\
\hline $\mathrm{TDF},{ }^{4}$ mucin corrected & $51.7^{\mathrm{a}}$ & $49.2^{\mathrm{b}}$ & $45.1^{\mathrm{c}}$ & 0.62 & $<0.001$ \\
\hline
\end{tabular}

${ }^{\mathrm{a}-\mathrm{C}} \mathrm{CP}$, CP-mucin, CP-NDF, Starch and TDF-mucin corrected should be moved to the left. Mean values in the same row with a different superscript differ $(P<0.05)$.

${ }^{1} n=10$ rabbits/diet. Covariate DMI was significant $(P<0.01)$ for all traits.

${ }^{2} \mathrm{CP}$ from intestinal mucin. $\mathrm{DF}=$ total dietary fiber.

${ }^{3} \mathrm{CP}$ linked to NDF.

${ }^{4}$ Total dietary fiber corrected for mucins.

0.01 ; Fig. 2) but similar for those given the HSF diet $(9.4$ vs. $8.1 \mathrm{~g} / \mathrm{d})$. The method used to quantify soluble fiber did not affect its ileal digestibility but influenced its cecal digestibility, being lower for TDF-NDF than for the other 2 methods ( 65.0 vs. $75.8 \% ; P=0.031)$, and consequently the interaction fiber method $\times$ site of fermentation was significant $(P=0.004)$. The fecal digestibility of soluble fiber increased with the dietary soluble fiber level $(P<0.001$; Table 5). Moreover, its value decreased successively $(P<0.01)$ when it was determined as TDF-IDF, TDF-in vitro insoluble fiber, and TDF-NDF. An interaction diet $\times$ method was found for fecal digestibility of soluble fiber $(P<0.01$; Table 5), because it was lower for the LSF compared with the HSF diet group, but for TDF-IDF, rabbits fed LSF and HSF diets showed similar values. Once corrected for fecal mucin content, fecal digestibility of soluble fiber increased by $2.0 \%$ units $(P<0.01)$. The amounts of fermented TDF-NDF, TDF-IDF, and TDF-in vitro insoluble fiber in the whole digestive tract were highly correlated $(r \geq 0.969, P<0.01)$. This correlation remained high between the amount of fermented TDF-NDF and TDF-IDF, in both the ileum and cecum $(r \geq 0.830, P<0.01)$. However, the correlation among the amount of fermented TDF-in vitro insoluble fiber and TDF-NDF or TDF-IDF in the ileum decreased (from 0.541 to $0.580 ; P<0.05$ ) or even disappeared in the cecum. All the interactions not mentioned were not significant.

Rabbits fed the LSF diet showed the lowest ileal flow of total and mucin CP $(P<0.01$; Table 6$)$. No effect was observed in the ileal flow of DM, OM, CP linked to NDF, and starch, but the TDF ileal flow (cor- 
Table 7. Effect of type of fiber (low soluble fiber [LSF], medium soluble fiber [MSF], or high soluble fiber [HSF] diet) and fiber method on ileal flow $(\mathrm{g} / \mathrm{d})$ of dietary insoluble fiber and soluble fiber, corrected for ileal mucin content, in rabbits

\begin{tabular}{lcc}
\hline \hline Item & Insoluble fiber & Soluble fiber \\
\hline Diets & & \\
LSF & $41.3^{\mathrm{a}}$ & 11.9 \\
MSF & $37.6^{\mathrm{b}}$ & 10.8 \\
HSF & $34.0^{\mathrm{c}}$ & 11.5 \\
Method $^{1}$ & & \\
IDF & 38.0 & 11.0 \\
In vitro insoluble fiber & 37.5 & 11.2 \\
NDF & 37.4 & 11.2 \\
SEM & & 0.91 \\
$P$-value & 0.92 & \\
Type of fiber (diet) & & 0.248 \\
Fiber method & $<0.001$ & 0.637 \\
Type of fiber $\times$ fiber method & 0.711 & 0.513 \\
\hline
\end{tabular}

${ }^{\mathrm{a}-\mathrm{c}}$ Mean values in the same column for each site of fermentation with a different superscript differ $(P<0.05)$.

${ }^{1} \mathrm{IDF}=$ insoluble dietary fiber; NDF $=\boldsymbol{\alpha}$-amylase NDF corrected for ash and protein.

${ }^{2} n=10$. Covariate DMI was significant $(P<0.01)$ for all traits.

rected for mucin) decreased when the soluble fiber increased $(P<0.01)$. Independent of the method used, the ileal flow of insoluble fiber was higher for rabbits fed the LSF compared with the HSF diet group (41.3 vs. $34.0 \mathrm{~g} / \mathrm{d} ; P<0.01$; Table 7). Ileal flow of soluble fiber (corrected for ileal mucin) was unaffected by the diet and by the method of analysis ( $11.1 \mathrm{~g} / \mathrm{d}$, on average).

\section{DISCUSSION}

This work confirms that increasing soluble fiber (by the inclusion of sugar beet and apple pulp) improves fecal TDF digestibility as reported previously (Trocino et al., 2011; Xiccato et al., 2011). The dietary soluble fiber represents around $50 \%$ of the total fermented TDF, despite its low proportion in the diet, and it is independent of the diet. This is explained by both the high fecal digestibility of soluble fiber, which is very close to that of starch (91.4 vs. $99.5 \%$, respectively), and the improved fecal digestibility of insoluble fiber when the soluble fiber increases. Ingredients rich in soluble fiber (sugar beet or citrus pulps) showed greater fecal digestibility of insoluble fiber than other common sources of fiber such as wheat bran, dehydrated alfalfa, or straw, which is mainly caused by their low degree of lignification (Martínez Pascual and Fernández Carmona, 1980; Gidenne, 1987; Pérez de Ayala et al., 1991).

The identification of the site of fermentation of soluble fiber and TDF (or nonstarch polysaccharides) is complex because of their usually low or even negative ileal digestibility found in this study or in previous work performed in pigs (Graham et al., 1986; Jørgensen et al., 1996) and rabbits (Gidenne, 1992; Martínez-Vallespín et al., 2013). This circumstance has been related in pigs with a potential interference of endogenous substances with these determinations (Graham et al., 1986; Jørgensen et al., 1996; Wilfart et al., 2007). In fact, Abad et al. (2013) observed that rabbit intestinal mucins were retained within the soluble fiber fraction when the latter was quantified in the intestinal digesta as both precipitate with ethanol. Consequently, a correction to avoid this problem was proposed. After applying this correction in the current study, the ileal TDF and soluble fiber digestibility increased. In addition, soluble fiber digestibility became positive for rabbits fed the diets with the lowest soluble fiber content.

Ileal digestibility of TDF (corrected for mucins) represented on average $40 \%$ of the fecal TDF digestibility and it was positively influenced by soluble fiber inclusion. This value is similar to that obtained previously in pigs (Mathers, 1991) or rabbits (Gidenne, 1992; García et al., 1999; Carabaño et al., 2001), when the digestibilities of dietary fiber monomers were determined. The increase of soluble fiber in the diet improved the ileal digestibility of insoluble and soluble fiber (corrected for mucins). The amount of fermented insoluble fiber in the ileum was higher than the amount of fermented soluble fiber (once corrected for mucins) for rabbits who received the LSF and MSF diets ( 72 vs. $28 \%$ out of the total ileal fermented TDF). When the soluble fiber content of the diet increased, as in the HSF diet, the rate of fermentation in the ileum was similar for insoluble and soluble fiber (52 vs. $48 \%$ out of the total ileal fermented TDF). These results are explained by the higher proportion of insoluble fiber in the diet (especially in the LSF and MSF diets) and the similar ileal digestibility of insoluble and soluble fiber. However, the amount of insoluble fiber fermented in the ileum is surprisingly high taking into account the relative short oroileal mean retention time of the digesta (around 5 h; Gidenne, 1994; García et al., 1999). In addition, a higher ileal digestibility of the soluble fiber fraction compared to the insoluble fiber fraction would have been expected because it is easily available and the pectinase activity in the rabbit small intestine is higher than the xylanase and cellulase activity (Marounek et al., 1995). A minor proportion of the insoluble fiber digestibility in the ileum may be explained by its partial solubilization in the acid conditions of the stomach, as observed when determining the 2-step pepsin/pancreatin in vitro NDF digestibility (from 6 to 1\% for the HSF diet and the average of the LSF and HSF diets, respectively; unpublished data). Similarly, a high ileal NDF digestibility was also found in rabbits given diets containing dehydrated alfalfa $(50 \%)$ or dehydrated alfalfa and sugar beet pulp (20 and 30\%) as the main sources of fiber ( 39 and $43 \%$, respectively; 
Merino and Carabaño, 1992). Other authors also reported a positive insoluble fiber digestibility before the cecum in rabbits (from 7 to $19 \%$ for crude fiber [Yu et al., 1987], $5 \%$ for NDF [Gidenne and Ruckebusch, 1989], and 16\% for NDF [Blas et al., 2003]), ponies (13\% for NDF; Hintz et al., 1971), and pigs (from negative values to $43 \%$ for NDF [Keys and DeBarthe, 1974], from 7 to 53\% for IDF [Graham et al., 1986], and 17\% for NDF [Schulze et al., 1994]). These results seem to confirm the occurrence of a significant hydrolysis of cell wall polysaccharides (soluble and insoluble) in the ileum, which might be performed by extracellular fibrolytic enzymes (Abbott and Boraston, 2008), as observed in the rabbit cecum (Sirotek et al., 2001). It might suggest that the cell wall polysaccharides in the ileum can be hydrolyzed to carbohydrates with lower molecular weight (to shorter polysaccharides or to oligosaccharides) as opposed to being extensively fermented. In fact, the molecular weight of $\beta$-glucan of oats was reduced after passage through the stomach and the proximal small intestine of pigs. It was probably associated to the microbial enzymes, although this activity did not lead to a loss in $\beta$-glucan from the digesta before the lower small intestine was reached (Johansen et al., 1993). Consequently, low molecular weight carbohydrates derived from microbial fiber hydrolisis would not be retained in the insoluble fiber fraction or precipitated with ethanol. This result may be explained by the fact that some bacteria possesses polysaccharide depolymerases but not glycoside hydrolases necessary for utilization of the xylooligosaccharides or oligogalacturonides as an energy source leading to the solubilization but not fermentation of cell wall polysaccharides (Dehority, 1993). In this way, Fondevila and Dehority (1994) demonstrated that ruminal hemicellulose utilization resulted from initial solubilization of the hemicellulose from the forage by nonhemicellulose utilizers and subsequent fermentation of this soluble polysaccharide by the utilizing, but nondegrading, bacteria. This circumstance may occur in rabbits fed high soluble fiber diets and may affect the ileal microbiota profile and gut health. El Abed et al. (2013) reported a reduction in ileal biodiversity in rabbits fed a diet including sugar beet pulp, although this effect was not observed by Gómez-Conde et al. (2007).

The majority of TDF was fermented in the cecum (60\%, which corresponds to $15.9 \mathrm{~g} \mathrm{TDF} / \mathrm{d}$, on average), and the TDF fermented in the cecum was not affected by dietary treatments. The soluble fiber represented $61 \%$ of the total TDF fermented in the cecum $(9.7 \mathrm{~g} / \mathrm{d}$, on average). This was in agreement with the higher fibrolytic activity found in the cecum, which was around 8.5 times higher than in the ileum (Marounek et al., 1995), and the longer mean retention time in the cecum and colon (around 9 h; Gidenne et al., 2010). The most important cecal fibrolytic activity found in rabbits fed alfalfa- and sugar beet pulp-based diets was the pectinase activity, whereas the cellulolytic activity was the least important (Falcao e Cunha et al., 2004). These authors observed that cecal pectinolytic activity was overcome only by xylanolytic activity in rabbits fed a wheat bran-based diet.

The method for quantifying insoluble fiber had no influence on the ileal and cecal digestibility of this fraction or on the amount of fermented insoluble fiber in each segment. However, its fecal digestibility was slightly higher when using NDF compared with IDF or in vitro insoluble fiber, leading to a higher amount of insoluble fiber fermented when determined using NDF respect to the value obtained with in vitro insoluble fiber (13.3 vs. 12.1 $\mathrm{g}$ insoluble fiber/d; $P=0.023)$. These differences are not relevant and might be explained by the higher solubilization of hemicelluloses in the feces than in the ingredients when the detergent method is used, compared with an enzymatic-chemical method, as reported by Hindrichsen et al. (2006). In fact, the correlation among the amount of insoluble fiber fermented in the whole digestive tract using the 3 methods was high. This correlation remained high for the insoluble fiber fermented in the ileum and cecum when it was calculated as NDF and IDF, but the TDF fermented in the cecum decreased for the insoluble fiber fermented in the cecum when in vitro insoluble fiber was used or even disappeared in the ileum. Similarly, the method for quantifying soluble fiber had no influence on the quantification of its ileal digestibility but influenced the cecal and fecal digestibility of this fraction, being lower for TDF-NDF digestibility. Nevertheless, for practical purposes, the method used to determine soluble fiber digestibility had no effect on the amount of soluble fiber fermented either in the ileum or in the cecum. The differences obtained for fecal soluble digestibility among diet groups due to the method used did not change the differences between the extreme diets, but it would suggest that the differences in the digestibility of extreme diets might increase when the soluble fiber digestibility is estimated using TDF-in vitro insoluble fiber. The correlation among the amount of soluble fiber fermented in the whole digestive tract using the 3 methods was high. This correlation remained high in the ileum and cecum when the soluble fiber fermented was calculated as NDF and IDF, but this correlation decreased for the soluble fiber fermented in the ileum and cecum when in vitro insoluble fiber was used. This result may be related to the different recovery of solubilized (partial or total) polysaccharides by the insoluble fiber methods. Accordingly, the nutritional meaning of the 3 different methodologies does not differ at the fecal level (especially when the amount of fermented fiber is considered). However, the meaning of the values obtained with the in vitro insoluble fiber method might differ from those obtained with NDF and IDF at both ileal and cecal levels. 
The observed positive effect of soluble fiber on ileal mucin flow agrees with the higher number of goblet cells per villi found in the jejunum when the soluble fiber is increased in rabbits (El Abed et al., 2011) and rats (Ito et al., 2009). The minor differences detected in the mucin flow at the fecal level indicated that mucins are extensively fermented by cecal bacteria, as observed in vitro by Marounek et al. (2000). In fact, the amount of mucins fermented in the cecum of rabbits fed the HSF diet represented around $50 \%$ of the amount of soluble fiber fermented ( 5.0 vs. $9.8 \mathrm{~g} / \mathrm{d}$ ), whereas this proportion decreased for those fed the LSF diet (2.7 vs. $9.0 \mathrm{~g} / \mathrm{d}$ ). The potential effects exerted by the inclusion of soluble fiber through raising the mucin production in the intestinal mucosa or in the cecum, as a substrate for microbial fermentation, might be related to the positive effect of soluble fiber on mortality rate in growing rabbits (Martínez-Vallespín et al., 2011; Trocino et al., 2013).

In conclusion, the ileal and cecal digestibility of TDF and soluble fiber should be corrected for the ileal and fecal mucin content. The method selected to measure insoluble and soluble fiber did not have a relevant influence on the amount of the fermented fiber fractions. Additionally, the increment of soluble fiber using sugar beet and apple pulp increased the amount of TDF fermented, due to the increasing proportions of both the insoluble and soluble fiber fractions fermented/solubilized in the ileum.

\section{LITERATURE CITED}

Abad, R., M. A. Ibáñez, R. Carabaño, and J. García. 2013. Quantification of soluble fibre in feedstuffs for rabbits and evaluation of the interference between the determinations of soluble fibre and intestinal mucin. Anim. Feed Sci. Technol. 182:61-70. doi:10.1016/j.anifeedsci.2013.04.001.

Abbott, D. W., and A. B. Boraston. 2008. Structural biology of pectin degradation by Enterobacteriaceae. Microbiol. Mol. Biol. Rev. 72:301-316. doi:10.1128/MMBR.00038-07.

AOAC. 2000. Official methods of analysis. 17th ed. AOAC Int., Arlington, VA.

Blas, E., L. Falcao, T. Gidenne, C. Scapinello, V. Pinheiro, A. I. García, and R. Carabaño. 2003. Interlaboratory study on ileal digestibility in rabbits: The effect of digesta collection time and a simplification of the procedure. World Rabbit Sci. 11:101-111.

Carabaño, R., J. García, and J. C. Blas. 2001. Effect of fibre source on ileal apparent digestibility of non-starch polysaccharicies in rabbits. Anim. Sci. 72:343-350.

de Blas, C., and G. G. Mateos. 2010. Feed formulation. In: C. de Blas and J. Wiseman, editors, The nutrition of the rabbit. 2nd ed. CABI Publishing, CAB International, Wallingford, UK. p. 222-232.

De Blas, J. C., G. G. Mateos, and P. G. Rebollar, editors. 2003. Tablas FEDNA de composición y valor nutritivo de alimentos para la fabricación de piensos compuestos. 2nd ed. (In Spanish.) Fundación Española para el Desarrollo de la Nutrición Animal, Madrid, Spain.
Dehority, B. A. 1993. Microbial ecology of cell wall fermentation. In: H. G. Jung, D. R. Buxton, R. D. Hatfield, and J. R. Madison, editors, Forage cell wall structure and digestibility. American Society of Agronomy, Inc., Crop Science Society of America, Inc., and Soil Science Society of America, Inc., Madison, WI. p. 425-453.

El Abed, N., I. Badiola, A. Pérez de Rozas, J. González, D. Menoyo, R. Carabaño, and J. García. 2013. Effect of soluble and insoluble fractions of sugar beet pulp on ileal and caecal microbiota of rabbits after weaning. World Rabbit Sci. 21:207-208.

El Abed, N., R. Delgado, R. Abad, C. Romero, M. J. Villamide, D. Menoyo, R. Carabaño, and J. García. 2011. Soluble and insoluble fibre from sugar beet pulp enhance intestinal mucosa morphology in young rabbits In: Proc. 62nd Annual meeting of the European Federation (held in Stavanger, Norway) of Animal Science, Book of abstracts. Wageningen Academic Publishers, Wageningen, The Netherlands. p. 159. (abst.)

Falcao e Cunha, L., H. Peres, J. P. B. Freire, and L. Castro-Solla. 2004. Effects of alfalfa, wheat bran or beet pulp, with or without sunflower oil, on caecal fermentation and on digestibility in the rabbit. Anim. Feed Sci. Technol. 117:131-149. doi:10.1016/j.anifeedsci.2004.07.014.

Fondevila, M., and B. A. Dehority. 1994. Degradation and utilization of forage hemicellulose by rumen bacteria, singly, in coculture or added sequentially. J. Appl. Bacteriol. 77:541-548. doi:10.1111/j.1365-2672.1994.tb04399.x.

García, J., R. Carabaño, and J. C. De Blas. 1999. Effect of fiber source on cell wall digestibility and rate of passage in rabbits. J. Anim. Sci. 77:898-905.

Gidenne, T. 1987. Effet de l'addition d'un concentré riche en fibres dans une ration à base de foin, distribuée á deux niveaux alimentaires chez la lapine adulte. 2. Measures de digestibilité. (In French.) Reprod. Nutr. Dev. 27:801-810. doi:10.1051/ rnd: 19870606.

Gidenne, T. 1992. Effect of fibre level, particle size and adaptation period on digestibility and rate of passage as measured at the ileum and in the faeces in the adult rabbit. Br. J. Nutr. 67:133-146. doi:10.1079/BJN19920015.

Gidenne, T. 1994. Effets d'une reduction de la tener en fibres alimentaires sur le transit digestif du lapin. Comparaison et validation de modéles d'ajustement des cinétiques d'excrétion fécale des marqueurs. (In French.) Reprod. Nutr. Dev. 34:295-307. doi:10.1051/rnd:19940403.

Gidenne, T., T. Bouyssou, and Y. Ruckebusch. 1988. Sampling of digestive contents by ileal cannulation in the rabbit. Anim. Prod. 46:147-151. doi:10.1017/S0003356100003214.

Gidenne, T., R. Carabaño, J. García, C. D. Blas, and J. Wiseman. 2010. Fibre digestion. In: C. de Blas and J. Wiseman, editors, The nutrition of the rabbit. 2nd ed. CABI Publishing, CAB International, Wallingford, UK. p. 66-82.

Gidenne, T., and Y. Ruckebusch. 1989. Flow and passage rate studies at the ileal level in the rabbit. Reprod. Nutr. Dev. 29:403-412. doi:10.1051/rnd:19890402.

Gómez-Conde, M. S., J. García, S. Chamorro, P. Eiras, P. G. Rebollar, A. Pérez de Rozas, I. Badiola, C. De Blas, and R. Carabaño. 2007. Neutral detergent soluble fibre improves gut barrier function in $25 \mathrm{~d}$ old weaned rabbits. J. Anim. Sci. 85:3313-3321. doi:10.2527/jas.2006-777.

Graham, H., K. Hesselman, and P. Aman. 1986. The influence of wheat bran and sugar-beet pulp on the digestibility of dietary components in a cereal-based pig diet. J. Nutr. 116:242-251.

Hindrichsen, I. K., M. Kreuzer, J. Madsen, and E. Bach Knudsen. 2006. Fiber and lignin analysis in concentrate, forage, and feces: Detergent versus enzymatic-chemical method. J. Dairy Sci. 89:2168-2176. doi:10.3168/jds.S0022-0302(06)72287-1. 
Hintz, H. F., D. E. Hogue, E. F. Walker Jr., J. E. Lowe, and H. F. Schryver. 1971. Apparent digestion in various segments of the digestive tract of ponies fed diets with varying roughagegrain ratios. J. Anim. Sci. 32:245-248.

Ito, H., M. Satsukawa, E. Arai, K. Sugiyama, K. Sonoyama, S. Kiriyama, and T. Morita. 2009. Soluble fiber viscosity affects both goblet cell number and small intestine mucin secretion in rats. J. Nutr. 139:1640-1647. doi:10.3945/jn.109.110171.

Johansen, H. N., P. J. Wood, and E. Bach Knudsen. 1993. Molecular weight changes in the $(1 \rightarrow 3)(1 \rightarrow 4)-\beta$-D-glucan of oats incurred by the digestive processes in the upper gastrointestinal tract of pigs. J. Agric. Food Chem. 41:2347-2352. doi:10.1021/jf00036a025.

Jørgensen, H., X. Q. Zhao, and B. Eggum. 1996. The influence of dietary fibre and environmental temperature on the development of the gastrointestinal tract, digestibility, degree of fermentation in the hind-gut and energy metabolism in pigs. Br. J. Nutr. 75:365-378. doi:10.1079/BJN19960140.

Keys, J. E., Jr., and J. V. DeBarthe. 1974. Cellulose and hemicellulose digestibility in the stomach, small intestine and large intestine of swine. J. Anim. Sci. 39:53-56.

Leterme, P., E. Froidmont, F. Rossi, and A. Théwis. 1998. The high water-holding capacity of pea inner fibers affects the ileal flow of endogenous amino acids in pigs. J. Agric. Food Chem. 46:1927-1934. doi:10.1021/jf970955+.

Littell, R., P. Henry, and C. Ammerman. 1998. Statistical analysis of repeated measures data using SAS procedures. J. Anim. Sci. 76:1216-1231.

Marounek, M., V. Skrivanova, and D. Duskova. 2000. In vitro caecal fermentation of nitrogenous substrates in rabbits. J. Agric. Sci. 135:437-442. doi:10.1017/S0021859699008345.

Marounek, M., S. J. Vovk, and V. Skrivanova. 1995. Distribution of activity of hydrolytic enzymes in the digestive tract of rabbits. Br. J. Nutr. 73:463-469. doi:10.1079/BJN19950048.

Martínez-Vallespín, B., E. Martínez-Paredes, L. Ródenas, C. Cervera, J. J. Pascual, and E. Blas. 2011. Combined feeding of rabbit female and young: Partial replacement of starch with acid detergent fibre or/and neutral detergent soluble fibre at two protein levels. Livest. Sci. 141:155-165. doi:10.1016/j.livsci.2011.05.014.

Martínez-Vallespín, B., E. Martínez-Paredes, L. Ródenas, V. J. Moya, C. Cervera, J. J. Pascual, and E. Blas. 2013. Partial replacement of starch with acid detergent fibre and/or neutral detergent soluble fibre at two protein levels: Effects on ileal apparent digestibility and caecal environment of growing rabbits. Livest. Sci. 154:123-130. doi:10.1016/j.livsci.2013.02.012.

Mathers, J. C. 1991. Digestion of non-starch polysaccharides by non-ruminant omnivores. Proc. Nutr. Soc. 50:161-172. doi:10.1079/PNS19910027.

Merino, J., and R. Carabaño. 1992. Effect of type of fibre on ileal and faecal digestibilities. J. Appl. Rabbit Res. 15:931-937.

Merino, J., and R. Carabaño. 2003. Efecto de la cecotrofia sobre la composición química de la digesta y sobre la digestibilidad ileal. (In Spanish.) ITEA 24:657-659.

Mertens, D. R., M. Allen, J. Carmany, J. Clegg, A. Davidowicz, M. Drouches, K. Frank, D. Gambin, M. Garkie, B. Gildemeister, D. Jeffress, C. S. Jeon, D. Jones, D. Kaplan, G. N. Kim, S. Kobata, D. Main, X. Moua, B. Paul, J. Robertson, D. Taysom, N. Thiex, J. Williams, and M. Wolf. 2002. Gravimetric determination of amylase-treated neutral detergent fiber in feeds with refluxing in beakers or crucibles: Collaborative study. J. AOAC Int. 85:1217-1240.
Monro, J. A. 1993. A nutritionally valid procedure for measuring soluble dietary fibre. Food Chem. 47:187-193. doi:10.1016/0308-8146(93)90242-8.

Martínez Pascual, J., and J. Fernández Carmona. 1980. Citrus pulp in diets for fattening rabbits. Anim. Feed Sci. Technol. 5:23-31. doi:10.1016/0377-8401(80)90007-3.

Perez, J. M., F. Lebas, T. Gidenne, L. Maertens, G. Xiccato, R. Parigi-Bini, A. Dalle Zotte, M. E. Cossu, A. Carazzolo, M. J. Villamide, R. Carabaño, M. J. Fraga, M. A. Ramos, C. Cervera, E. Blas, J. Fernandez, L. Falcao e Cunha, and J. Bengala Freire. 1995. European reference method for in vivo determination of diet digestibility in rabbits. World Rabbit Sci. 3:41-43.

Pérez de Ayala, P., M. J. Fraga, R. Carabaño, and J. C. de Blas. 1991. Effect of fiber source on diet digestibility and growth in fattening rabbits. J. Appl. Rabbit Res. 14:159-165.

Romero, C., N. Nicodemus, J. Rodríguez, A. García, and C. de Blas. 2011. Effect of type of grinding of barley and dehydrated alfalfa on performance, digestion, and crude mucin ileal concentration in growing rabbits. J. Anim. Sci. 89:24722484. doi: 10.2527/jas.2010-3226.

Schulze, H., P. van Leeuwen, M. W. A. Verstegen, J. Huisman, W. B. Souffrant, and F. Ahrens. 1994. Effect of level of dietary neutral detergent fiber on ileal apparent digestibility and ileal nitrogen losses in pigs. J. Anim. Sci. 72:2362-2368.

Sirotek, K., M. Marounek, V. Rada, and V. Benda. 2001. Isolation and characterization of rabbit caecal pectinolytic bacteria. Folia Microbiol. (Praha) 46:79-82. doi:10.1007/BF02825893.

Trocino, A., M. Fragkiadakis, D. Majolini, R. Carabaño, and G. Xiccato. 2011. Effect of the increase of dietary starch and soluble fibre on digestive efficiency and growth performance of meat rabbits. Anim. Feed Sci. Technol. 165:265-277. doi:10.1016/j.anifeedsci.2011.03.008.

Trocino, A., J. García, R. Carabaño, and G. Xiccato. 2013. A metaanalysis on the role of soluble fibre in diets for growing rabbits. World Rabbit Sci. 21:1-15. doi:10.4995/wrs.2013.1285.

Udén, P., P. E. Colucci, and P. J. Van Soest. 1980. Investigation of chromium, cerium and cobalt as markers in digesta. Rate of passage studies. J. Sci. Food Agric. 31:625-632. doi:10.1002/ jsfa.2740310702.

Van Soest, P., J. Robertson, and B. Lewis. 1991. Methods for dietary fiber, neutral detergent fiber, and nonstarch polysaccharides in relation to animal nutrition. J. Dairy Sci. 74:35833597. doi:10.3168/jds.S0022-0302(91)78551-2.

Wilfart, A., L. Montagne, P. Simmins, J. Van Milgen, and J. Noblet. 2007. Sites of nutrient digestion in growing pigs: Effect of dietary fiber. J. Anim. Sci. 85:976-983. doi:10.2527/jas.2006-431.

Xiccato, G., A. Trocino, D. Majolini, M. Fragkiadakis, and M. Tazzoli. 2011. Effect of decreasing dietary protein level and replacing starch with soluble fibre on digestive physiology and performance of growing rabbits. Animal 5:1179-1187. doi: $10.1017 / \mathrm{S} 1751731111000243$.

Xiccato, G., A. Trocino, M. Tazzoli, D. Majolini, R. Carabaño, M. J. Villamide, J. García, N. Nicodemus, R. Abad, E. Blas, C. Cervera, L. Ródenas, E. Martínez, and L. Falcao e Cunha, J. P. Bengala Freire, L. Maertens, C. Bannelier, M. Segura, and T. Gidenne. 2012. European ring-test on the chemical analyses of total dietary fibre and soluble fibre of compound diets and raw materials for rabbits. In: Proc. 10th World Rabbit Congress, Sharm El-Sheikh, Egypt. p. 453-471.

Yu, B., P. W. Chiou, C. Young, and H. Huang. 1987. A study of rabbit T-type cannula and its ileal digestibilities. J. Chin. Soc. Anim. Sci. 16:73-81. 